\title{
Elektrik Enerjisi Başarı Testinin Geliştirilmesi ${ }^{1}$
}

\section{Development of Electrical Energy Achievement Test}

\author{
Feyza DUMANOĞLU \\ MEB, Fen Bilimleri Öğretmeni \\ feyzadumanoglu@gmail.com \\ Behiye BEZİR AKÇAY \\ İstanbul Üniversitesi, Hasan Ali Yücel Ë̆itim Fakültesi, Matematik ve Fen Bilimleri Eğitimi Bölümü, \\ Fen Bilgisi Ĕgitimi Ana Bilim Dalı \\ bbezir@gmail.com
}

Atıf: Dumanoğlu, F. \& Bezir Akçay, B. (2018). Elektrik Enerjisi Başarı Testinin Geliştirilmesi. E-Kafkas Eğitim Araştırmaları Dergisi, 5(2), 20-39.

Gönderi Tarihi: 09-05-2018

Kabul Edilme Tarihi: $26-07-2018$

DOI: $10.30900 /$ kafkasegt.422251

$\ddot{O} z e t$

$\mathrm{Bu}$ araştırmanın amacı ortaokul yedinci sınıf fen bilimleri dersi elektrik enerjisi ünitesi kazanımlarına yönelik öğrencilerin akademik başarılarını ölçmeye elverişli bir başarı testi geliştirmektir. Öncelikle literatür taraması yapılmış, merkezi sınavlarda sorulan sorular bir araya getirilmiş ve 39 sorudan oluşan bir soru havuzu oluşturulmuştur. Benzer özellikteki sorular testten çıkarılmış ve soru sayısı 27'ye düşürülmüştür. Uzman görüşleri alınıp, gerekli düzenlemeler yapıldıktan sonra 27 sorudan oluşan Elektrik Enerjisi Başarı Testi (EEBT) 255 sekizinci sınıf öğrencine uygulanmıştır. Test sonuçlarından elde edilen veriler SPSS 24 ve LISREL programları kullanılarak analiz edilmiştir. Madde analizi ve doğrulayıcı faktör analizi sonunda iki madde testten çıkarılmıștır. 25 sorudan oluşan testin güvenirlik kat sayısı 0,79 olarak bulunmuştur. Başarı testinin 30 öğrenciye tekrar uygulanması sonucunda test-tekrar test güvenirliği 0.80 olarak hesaplanmıştır. Doğrulayıcı faktör analizi yapıldığında soruların "Ampulleri Bağlama Şekilleri” ve "Elektrik Enerjisinin Dönüşümü" faktörlerine dağıldığı ispatlanmıştır. Yapılan analizler sonucunda yedinci sınıf öğrencileri için geliştirilen 25 maddeden oluşan Elektrik Enerjisi Başarı Testinin (EEBT) geçerli ve güvenilir bir araç olduğu ortaya çıkmıştır.

Anahtar kelimeler: elektrik enerjisi, fen bilimleri, ölçek geliştirme, doğrulayıcı faktör analizi

\section{Abstract}

The aim of this study is to develop a measurement tool to assess students' academic achievement in Electrical Energy Unit. Firstly, 39 questions were collected from a variety of sources. Similar questions were eliminated and the number of questions was reduced to 27. Before first version of Electrical Energy Achievement Test (EEAT) consist of 27 items written according to objectives was applied 255 eight graders, the expert opinions were taken. Then, the data were analyzed via SPSS 24 and LISREL 9.30 programs. Based on item analysis and confirmatory factor analysis, two questions were removed. Reliability coefficient of Electrical Energy Achievement Test consisting of 25 questions was found 0.79 in this study. EEAT was administrated to 30 students as re-test and thus, test-retest reliability was found 0,80 . Confirmatory factor analysis was performed and two factors were found suitable. Name of the factors are "Connecting Light Bulbs" and "Transformation of Electrical Energy". This study indicates that the Electrical Energy Achievement Test consisting of 25 questions is valid and reliable instrument to assess seventh grade students' achievement.

Keywords: Electrical energy, science, science education, measurement tool, confirmatory factor analysis (CFA)

\section{GíRIŞ}

Ölçme ve değerlendirme eğitim-öğretim sürecinin ayrılmaz bir parçasıdır. Hedef davranışların ne düzeyde geliştiğini en doğru şekilde ölçmek, öğretim kalitesini iyileştirmek açısından oldukça önemlidir. Bu nedenle öğrenme öğretme süreciyle ölçme ve değerlendirme uygulamalarının eş güdümlü ve birbirini destekler nitelikte olması gerekir (Milli Eğitim Bakanlığı [MEB], 2017). Ölçme ve değerlendirmenin etkili ve uygun bir

\footnotetext{
${ }^{1} \mathrm{Bu}$ çalışma birinci yazarın yüksek lisans tezinin bir bölümünden uyarlanmıştır.
} 
şekilde kullanılması öğretimi kolaylaştırarak öğrencilerin öğrenmelerini artırır (Waugh ve Gronlund, 2013). Ölçme ve değerlendirmenin öncelikli hedefi öğrencilerin gelişimlerine yardımcı olmaktır (National Research Council [NRC], 2001).

İyi bir ölçme aracı öğrencilerin eksik olduğu tarafları ortaya çıkarmakla kalmaz aynı zamanda gelecekte hangi konularda veya alanlarda başarılı olabileceklerini öngörür; öğrencinin durumu hakkında öğrenciye, veliye ve öğretmene bilgi verir (Çelik, 2000). Bunun yanı sıra ölçme işleminin öğrenmeyi sağlama ve öğrenmeyi teşvik etme gibi unsurları da vardır (Marzano, 2006; Stiggins, Arter ve Chappuis, 2006) çünkü sınavlar öğrencilerin öğrenme hedeflerine yönelmeleri konusunda onları teşvik eder (Şan ve Akdağ, 2016).

Atılgan, Kan ve Doğan (2009)'a göre “Ölçme, bir nesnenin ya da bireyin belli bir niteliğe veya özelliğe ne derece sahip olduğunun belirlenmesi amacıyla yapılır" (s. 2). Ölçme ile kıyaslandığında daha geniş kapsamlı olan değerlendirme (Gezgincan, Murat ve Yalçın, 2005) ise ölçme sonuçlarına bağlı olarak yapılır (Atılgan, Kan ve Doğan, 2009). Değerlendirme ile sonuçlar hakkında bir yargıya varılması, sonuçların nitelendirilmesi amaçlanır. Kısaca açıklamak gerekirse, ölçme ile niteliği veya hedef davranışı betimlemek mümkün iken değerlendirme ile bir yargıya veya bir karara ulaşı1ır (Tekin, 1987).

Ölçme ve değerlendirme araçları olarak yazılı yoklamalar, sözlü sınavlar, kısa cevaplı-boşluk doldurmalı testler, doğru-yanlış testleri, eşleştirmeli madde testleri ve çoktan seçmeli testler kullanılabilmektedir. Çoktan seçmeli testleri hazırlamanın zaman alıcı olması, madde yazımının zor olması ve öğrenciye şans başarısı getirmesi bu tür ölçme araçlarının sınırlılıkları arasında yer alsa da faydaları azımsanamayacak kadar çoktur. Çoktan seçmeli testlerin, çok sayıda soru sorabilme ve dolayısıyla farklı bilgi ve becerileri ölçmeyi sağlama, objektif ve kolay puanlama imkanı verme, zaman açısından ekonomik olma, üst düzey davranışları ölçmeye elverişli olma gibi diğer test türlerine kıyasla üstün gelen özellikleri vardır (Atılgan vd., 2009; Erkan ve Gömleksiz, 2014). Araştırmada geliştirilen testin çoktan seçmeli sorulardan oluşturulmasının nedeni sağladığı bu avantajlardır.

Fen bilimleri ortaokul müfredatında yapılan değişiklikler yeni ünite başarı testlerine olan ihtiyacı ortaya çıkarmıştır. Literatürdeki aynı ünite başlıklı başarı testleri günümüz yedinci sınıf elektrik enerjisi ünitesi kazanımları ile birebir örtüşmemektedir. Literatürdeki elektrik enerjisi konusu ile ilgili başarı testleri genellikle altıncı sınıflara yöneliktir (Demirci ve Yağcı 2008; Günel, Atila ve Büyükkasap, 2009). İdin'in (2015) doktora tezi için hazırladığı başarı testi ile Coşkun, Akarsu ve Kariper'in(2012) geliştirdiği başarı testi ise 2006 müfredatına uygun olup değişen 2013 müfredatını karşılamamaktadır. Engelhardt ve Beichner'in (2002) başarı testi ise tüm kazanımları karşılamamaktadır.

Literatürdeki başarı testi eksikliği bu çalışmaya olan ihtiyacı ortaya çıarmıştır. Bu çalışmanın amacı yedinci sınıf öğrencilerinin fen bilimleri dersi Elektrik Enerjisi Ünitesi’ndeki akademik başarılarını değerlendirecek bir ölçme aracı geliştirmektir.

\section{YÖNTEM}

\section{Çalışma grubu}

Araştırmanın çalı̧̧ma grubunu 2016-2017 eğitim öğretim yılında İstanbul ilinde bulunan üç farklı okuldaki 255 (131 kız, 124 erkek) ortaokul 8. sınıf öğrencisi oluşturmaktadır. Ölçeğin elektrik enerjisi ünitesini fen bilimleri dersinde işlemiş öğrencilere uygulanması gerektiği için sekizinci sınıf öğrencilerine uygulanmıştır. Ölçek geliştirilmesi tamamlandıktan sonra yedinci sınıflarda uygulamaya hazır hale getirilmiştir.

\section{Testin geliştirilmesi}

Testin geliştirilmesinde aşağıda verilen işlem basamakları takip edilmiştir (Seçer, 2015a):

1. Test ihtiyacının belirlenmesi

2. Literatür taraması ve soru havuzunun oluşturulması

3. Madde yazımı

4. Belirtke tablosunun oluşturulması

5. Uzman görüşü alma

6. İlk taslak formun oluşturulması 


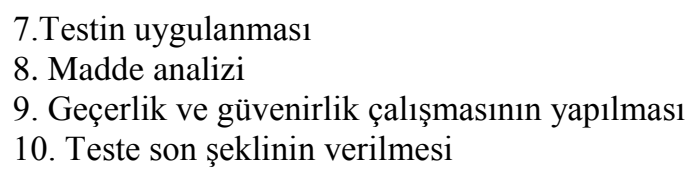

Test ihtiyacının belirlenmesi: Literatürde “Elektrik Enerjisi” ünitesine yönelik hazırlanan başarı testleri 2013 yılında MEB tarafından yayınlanan Fen Bilimleri Dersi Öğretim Programında yer alan kazanımları karşılamamaktadır. Bu nedenle yedinci sınıf öğrencilerinin “Elektrik Enerjisi” ünitesine yönelik akademik başarılarını değerlendirebilecek bir başarı testi geliştirilmesi gerektiğine karar verilmiştir.

Literatür tarama ve soru havuzunun oluşturulması: Başarı testi geliştirmek için öncelikle "Elektrik Enerjisi" ünitesi kazanımları dikkatlice okunmuş, ders kitabındaki ifadeler ve örnek sorular incelenmiş ve ilgili alan yazın taraması yapılmıştır. Ortaokul 6,_7 veya 8. sınıf öğrencilerine yönelik hazırlanmış olan başarı testleri, bakanlık tarafindan yapılan merkezi sınavlarda (Ortaöğretim Kurumları Öğrenci Seçme ve Yerleştirme Sınavları (OKS ve LGS), Parasız Yatılılık ve Bursluluk Sınavı (PYBS), Seviye belirleme Sınavı (SBS)...vb.) sorulan çoktan seçmeli sorular, Eğitim Bilişim Ağında (EBA) verilen örneklerdeki sorular ve araştırmacı tarafindan geliştirilen sorular bir araya getirilerek 39 soruluk bir soru havuzu oluşturulmuştur.

Madde yazımı: Soru havuzu incelenmiş, aynı kazanımı ölçen ve benzer özellikteki sorulardan oluşan 12 soru testten çıkarıldıktan sonra kalan 27 soru araştırmacı tarafindan kapsamı, hedef kazanımı ve amacı aynı kalmak suretiyle yeniden yazılmış ve 27 çoktan seçmeli sorudan oluşan başarı testinin ilk taslak formu elde edilmiştir.

Testteki 2, 5, 6, 7, 9, 11, 18, 19, 21, 22, 23, 24, 25 ve 27 numaralı sorular araştırmacı tarafindan geliştirilen sorulardır. Testteki 1, 3, 4, 8, 10, 12, 13, 14, 15, 16, 17, 20 ve 26 numaralı sorular ise Tablo 1'de belirtilen kaynaklardaki soruların öğrenci seviyesine, müfredat kazanımlarına uygun hale getirilmesiyle oluşturulmuştur.

Tablo 1 .

Elektrik Enerjisi Başarı Testi (EEBT) sorularının kaynakları

\begin{tabular}{lll}
\hline Test sorusu & $\begin{array}{l}\text { Benzer soru yazımında kullanılan } \\
\text { kaynak }\end{array}$ & Orijinal kaynaktaki soru numaraları \\
\hline Soru 1 & Engelhardt \& Beichner (2002) & 9. Soru ve 18. Soru \\
Soru 3 & 2011 SBS 7. Sinıf & 1. Soru \\
Soru 4 & 2012 PYBS 7. Sinif & 6. Soru \\
Soru 8 & 2011 TIMSS 8. Sinif & 51. Soru \\
& 2003 LGS 8. Sinif & 9. Soru \\
Soru 10 & 2009 SBS 7. Sinif & 4. Soru \\
& 2013 PYBS 7. Sinif & 6. Soru \\
Soru 12 & 2010 SBS 7. Sinif & 7. Soru \\
Soru 13 & 2016 PYBS 7. Sinif & 7. Soru \\
& 2008 SBS 7. Sinif & 3. Soru \\
& 2006 OKS 8. Sinif & 5. Soru \\
Soru 14 & 2007 OKS 8. Sinif & 4. Soru \\
Soru 15 & 2008 SBS 7. Sinif & 4. Soru \\
Soru 16 & 2012 PYBS 7. Sinif & 5. Soru \\
Soru 17 & Engelhardt \& Beichner (2002) & 5. Soru \\
Soru 20 & 2010 SBS 8. Sinif & 13. Soru \\
& 2012 SBS 8. Sinif & 20. Soru \\
Soru 26 & 2016 PYBS 7. Sinif & 3. Soru \\
\hline
\end{tabular}

Belirtke tablosu oluşturma: Başarı testinin kapsam geçerliliğini sağlamak için belirtke tablosu oluşturulmuştur (Tablo 2). Tabloda her sorunun hangi kazanımı ölçtüğü belirtilmiştir. Ayrıca her sorunun yenilenen Bloom taksonomisine göre bilişsel basamağ 
Tablo 2.

EEBT belirtke tablosu

\begin{tabular}{|c|c|c|}
\hline Konu & Kazanım & $\begin{array}{l}\text { Soru } \\
\text { Numarasi }\end{array}$ \\
\hline \multirow[t]{7}{*}{$\begin{array}{l}\text { Ampullerin Bağlanma } \\
\text { Şekilleri }\end{array}$} & $\begin{array}{l}\text { 7.6.1.1 Seri ve paralel bağlamanın nasıl olduğunu keşfeder, seri } \\
\text { ve paralel bağll ampullerden oluşan bir devre şeması çizer. }\end{array}$ & 4,17 \\
\hline & $\begin{array}{l}\text { 7.6.1.2. Ampullerin seri ve paralel bağlandığ }{ }^{\circ} \text { durumlardaki } \\
\text { parlaklık farklılıklarını devre üzerinde gözlemler ve sonucu } \\
\text { yorumlar. }\end{array}$ & $\begin{array}{l}6,10,12 \\
13,14\end{array}$ \\
\hline & $\begin{array}{l}\text { 7.6.1.3. Elektrik enerjisi kaynaklarının elektrik devrelerine } \\
\text { elektrik akımı sağladığını ve elektrik akımının bir çeşit enerji } \\
\text { aktarımı olduğunu bilir. }\end{array}$ & 1,2 \\
\hline & $\begin{array}{l}\text { 7.6.1.4. Ampermetreyi devreye seri bağlayarak okuduğu değeri } \\
\text { akım şiddeti olarak adlandırır ve birimini ifade eder. }\end{array}$ & $3,5,8$ \\
\hline & $\begin{array}{l}\text { 7.6.1.5. Voltmetreyi devreye paralel bağlayarak devre uçları } \\
\text { arasındaki gerilimi (potansiyel farkı) ölçer ve birimini ifade eder. }\end{array}$ & 9 \\
\hline & $\begin{array}{l}\text { 7.6.1.6. Bir devre elemanının uçları arasındaki gerilim ile } \\
\text { üzerinden geçen akım arasındaki ilişkiyi deneyerek keşfeder. }\end{array}$ & $11,15,16$ \\
\hline & $\begin{array}{l}\text { 7.6.1.7. Ampullerin seri ve paralel bağlandığı durumlardaki } \\
\text { parlaklık farklılığının sebebini elektriksel dirençle ilişkilendirir. }\end{array}$ & 7,18 \\
\hline \multirow[t]{5}{*}{$\begin{array}{l}\text { Elektrik Enerjisinin } \\
\text { Dönüşümü }\end{array}$} & $\begin{array}{l}\text { 7.6.2.1. Elektrik enerjisinin } 1 \mathrm{~s} 1 \text { ve } 1 \text { şı } 1 \mathrm{k} \text { enerjisine dönüştüğüne } \\
\text { ilişkin deneyler yapar ve sonucu gözlemler. }\end{array}$ & 21 \\
\hline & $\begin{array}{l}\text { 7.6.2.2. Elektrik enerjisinin } 1 \mathrm{~s} 1 \text { ve } 1 \text { şık enerjisine dönüşümünü } \\
\text { temel alan teknolojik uygulamalara örnekler verir. }\end{array}$ & 23,26 \\
\hline & $\begin{array}{l}\text { 7.6.2.3. Elektrik enerjisinin hareket enerjisine, hareket enerjisinin } \\
\text { de elektrik enerjisine dönüştüğünü kavrar. }\end{array}$ & 19,21 \\
\hline & $\begin{array}{l}\text { 7.6.2.4. Güç santrallerinde elektrik enerjisinin nasıl üretildiğini } \\
\text { araştırır ve sunar. }\end{array}$ & $\begin{array}{l}20,22,23 \\
24\end{array}$ \\
\hline & $\begin{array}{l}\text { 7.6.2.5. Elektrik enerjisinin bilinçli ve tasarruflu kullanılmasının } \\
\text { aile ve ülke ekonomisi bakımından önemini tartışır. }\end{array}$ & 25,27 \\
\hline
\end{tabular}

“Elektrik enerjisi” ünitesi ile ilgili her kazanıma ait birkaç soru yazılmıştır. Bazı sorular birden fazla kazanımı ölçmeye yöneliktir. Kazanımların dengeli şekilde dağılmasına özen gösterilmiş ve kapsam geçerliği sağlanmıştır.

Webb'in (2007) denge indeksi (balance index) kullanılarak soruların kazanımlara göre dağılımı incelenmiştir. Denge İndeksi $=1-(\Sigma|1 /(\mathrm{O})-\mathrm{I}(\mathrm{k}) /(\mathrm{H})|) / 2$ formülü kullanılarak hesaplanmaktadır. Bu formülde $\mathrm{O}=$ testte yer alan toplam kazanım sayısını, $\mathrm{I}(\mathrm{k})=$ kazanım başına düşen soru sayısını ve $\mathrm{H}=$ toplam soru sayısını ifade etmektedir.

Formül kullanıldığında denge indeksi $1-(|1 / 12-2 / 27|+|1 / 12-5 / 27|+|1 / 12-2 / 27|+|1 / 12-3 / 27|+\mid 1 / 12-$ $1 / 27|+| 1 / 12-3 / 27|+| 1 / 12-2 / 27|+| 1 / 12-1 / 27|+| 1 / 12-2 / 27|+| 1 / 12-2 / 27|+| 1 / 12-4 / 27|+| 1 / 12-2 / 27 \mid) / 2=0.81$ olarak hesaplanmıştır. Bu değer testteki soru dağılımının dengeli olduğunu göstermektedir.

Test sorularının bilişsel düzeyleri Tablo 3'te verilmiştir. Soruların çoğu anlama (6 soru) ve değerlendirme (10 soru) düzeyindedir. Çoktan seçmeli soru tipi yaratma düzeyinde soru hazırlanmasına olanak sunmadığı için en fazla değerlendirme düzeyinde soru yazılmıştır. 
Tablo 3.

Test sorularının bilişsel düzeyleri (Anderson ve Krathwohl, 2001)

\begin{tabular}{ll}
\hline Bilişsel düzey & Soru sayısı \\
\hline Hatırlama & $7,22,26$ \\
Anlama & $2,4,5,9,19,24$ \\
Uygulama & $1,3,11$ \\
Analiz & $12,15,16,23$ \\
Değerlendirme & $6,8,10,13,14,17,18,21,25,27$ \\
Yaratma & - \\
\hline
\end{tabular}

Uzman görüşü alma: Başarı testine yönelik uzman görüşü alınması için uzman görüş formu oluşturulmuştur. Uzman görüş taslak formu Tablo 4'te gösterilmiştir. Bu formda madde adları sorul'den soru27'ye kadar yazılmış, her bir madde için uygun/uygun değil seçeneklerini işaretlemeleri beklenmiştir. Uygun değil seçeneğini işaretleyen uzmanlardan gerekçelerini/önerilerini/düzeltmelerini ilgili bölümü yazmaları istenmiștir.

Tablo 4

Uzman görüş formu taslă̆

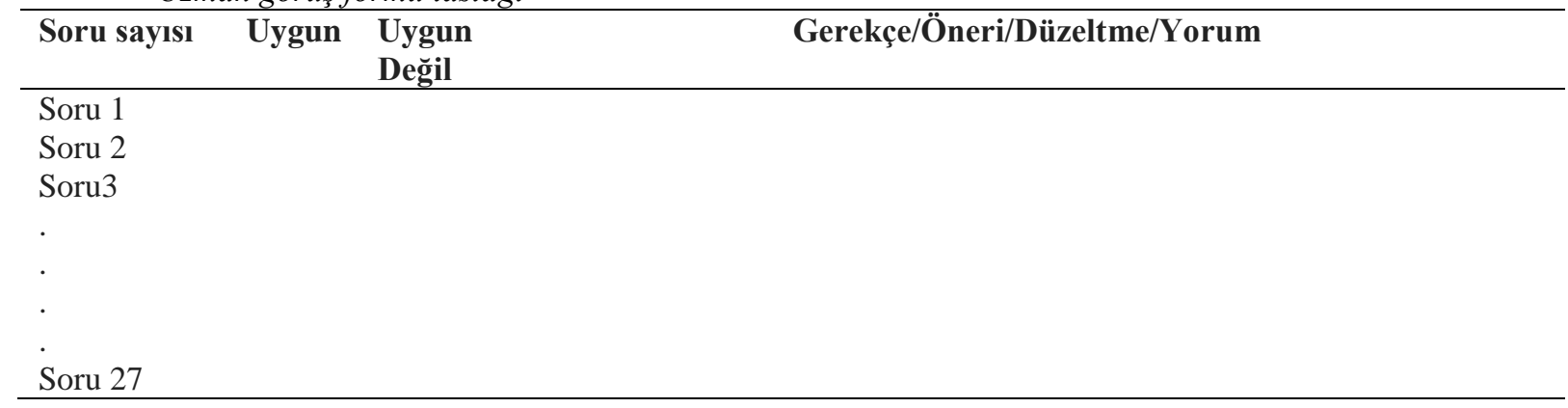

Başarı testi, 1 Fizik bölümü mezunu, 2 Türkçe öğretmeni, 4 Fen Bilimleri öğretmeni, 1 Uzman tarafından incelenmiştir. Soruların akıcılığı, soru öbeklerinin anlaşılırlığı, soruların hedef kitleye uygunluğu ve bilimsel bilgilerle tutarlılığı gibi faktörler göz önünde bulundurularak yapılan yorumlar dikkate alınarak gerekli düzenlemeler yapılmıştır. Uzman grubunun demografik özellikleri Tablo 5 'te verilmiştir.

Tablo 5 .

Uzman grubunun demografik özellikleri

\begin{tabular}{llll}
\hline Kod & Cinsiyet & Mesleki durum & Lisans derecesi \\
\hline 01 & Kadın & Araştırma Görevlisi & Fizik Bölümü \\
02 & Kadın & Türkçe Öğretmeni & Türkçe Öğretmenliği \\
03 & Kadın & Türkçe Öğretmeni & Türkçe Öğretmenliği \\
04 & Kadın & Fen Bilimleri Öğretmeni & Fen Bilimleri Öğretmenliği \\
05 & Kadın & Fen Bilimleri Öğretmeni & Fen Bilimleri Öğretmenliği \\
06 & Kadın & Fen Bilimleri Öğretmeni & Fen Bilimleri Öğretmenliği \\
07 & Erkek & Fen Bilimleri Öğretmeni & Fen Bilimleri Öğretmenliği \\
08 & Kadın & Öğretim Üyesi & Fen Bilgisi Eğitimi \\
\hline
\end{tabular}

Illk taslak formun oluşturulması: Uzman görüşü alınıp, gerekli düzenlemeler yapıldıktan sonra 27 sorudan oluşan başarı testine ilk şekli verilmiş, ölçek uygulamaya hazır hale getirilmiştir. Uygulamadan önce ölçek metninin başına öğrencilere başarı testinin uygulama amacının kısa ve öz bir şekilde anlatıldığı bir yönerge eklenmiştir.

Testin uygulanması: Elektrik Enerjisi Başarı Testi, 2016-2017 eğitim-öğretim yılında İstanbul'da üç farklı devlet okulunun 8. sınıflarında öğrenimlerine devam eden 255 öğrenciye uygulanmıştır. Haladyna (2004), örneklem büyüklüğünün 200'den fazla olmasının yeterli görüldüğünü belirtmiştir. Başka bir kaynakta katılımcı 
sayısının ölçekteki madde sayısının beş ya da on katı kadar olması gerektiği söylenmiştir. Bu çalışmada madde sayısının yaklaşık on katına tekabül eden 255 katılımcıya test uygulanmıştır (Akt:Seçer, 2015a).

Madde analizi: Öğrencilere uygulanan başarı testi puanları her doğru yanıta 1 puan, her yanlış yanıta 0 puan ve her boş bırakılan soruya 0 puan verilecek şekilde hesaplanmıştır. Öğrencilerin aldıkları puanlar en azdan en çok olana göre dizilmiş ve madde analizi için üst grubu oluşturan en iyi puan alan yüzde 27'lik öğrenci (69 öğrenci) ile alt grubu oluşturan en düşük puanı alan yüzde 27'lik (69 öğrenci) öğrenciler belirlenmiştir. Daha sonra madde analizi gerçekleştirilmiştir. Madde analizi makalenin bulgular kısmında ayrıntılı olarak anlatılıışır.

Geçerlik ve güvenirlik çalışmasının yapılması: Çalışmanın yapı geçerliği doğrulayıcı faktör analizi ile sınanmıştır. Geçerlik ve güvenirlik hesaplamaları bulgular kısmında ayrıntılı olarak verilmiştir.

Teste son şeklinin verilmesi: Araştırmanın bulgular kısmında gösterildiği gibi madde analizi ve doğrulayıcı faktör analizi sonucunda uygun olmadığı tespit edilen maddeler testten çıkarılmış, teste son şekli verilmiştir.

\section{Veri toplama ve verilerin analizi}

Başarı testinin pilot uygulaması 2016-2017 eğitim-öğretim y1lında İstanbul'da üç farklı devlet okulunun 8. sınıflarında öğrenimine devam eden 255 öğrenciyle yapılmıştır. Öğrencilerin doğru cevap verdikleri her soruya 1'er puan, yanlış cevap verdikleri veya boş bıraktıkları sorulara 0 puan verilmiştir. Testten alınabilecek maksimum puan 25, minimum puan ise 0'dır. Öğrencilerden toplanan veriler SPSS 24 ve Lisrel 9.30 programları kullanılarak analiz edilmiştir.

\section{BULGULAR}

\section{Kapsam geçerliği}

Geçerlik, ölçülmek istenen davranışı ölçme aracı ile ölçülebilip ölçülememesi ile ilgilidir (Seçer, 2015b; Heale ve Twycross, 2017). Kapsam geçerliği ise testteki maddelerin ölçülmek istenen niteliklere ne derece uyumlu olduğu ile ilgilidir. Kapsam geçerliğini sağlamak için öncelikle belirtke tablosu oluşturulmuş (Tablo 1), her bir kazanıma göre sorular hazırlanmıştır. Hazırlanan sorular daha sonra uzman görüşüne sunulmuştur. Başarı testi soruları 1 fizik bölümü mezunu, 4 fen bilimleri öğretmeni, 1 uzman tarafindan incelenmiş, kazanımlara uygunluğu değerlendirilmiştir. Webb'in (2007) denge indeksi (balance index) formülü kullanılarak yapılan hesaplanma testteki soru dağılımının dengeli olduğunu göstermiştir.

\section{Madde Analizi}

Sorulara doğru cevap veren üst grup $(n=69)$ ve alt gruptaki $(n=69)$ öğrencilerin sorulara verdiği doğru ve yanlış cevaplara bakılarak madde analizi yapılmıştır (Tablo 6).

Tablo 6

EEBT madde analizi

\begin{tabular}{cccccc}
\hline Soru No & $\mathbf{D}_{\mathbf{i}}$ & $\mathbf{D}_{\mathbf{a}}$ & $\mathbf{P}$ & $\mathbf{r}_{\mathbf{j}}$ & Sonuç \\
\hline 1 & 53 & 28 & 0.58 & 0.36 & İyi \\
2 & 59 & 25 & 0.60 & 0.49 & Çok İyi \\
3 & 31 & 6 & 0.26 & 0.36 & İyi \\
4 & 69 & 41 & 0.79 & 0.40 & Çok İyi \\
5 & 38 & 12 & 0.36 & 0.37 & İyi \\
6 & 29 & 7 & 0.26 & 0.31 & İyi \\
7 & 48 & 21 & 0.50 & 0.39 & İyi \\
8 & 55 & 13 & 0.49 & 0.60 & Çok İyi \\
9 & 54 & 12 & 0.47 & 0.60 & Çok Iyyi \\
10 & 54 & 14 & 0.49 & 0.57 & Çok İyi \\
11 & 43 & 18 & 0.44 & 0.36 & İyi
\end{tabular}




\begin{tabular}{cccccc}
12 & 61 & 34 & 0.68 & 0.39 & İyi \\
13 & 44 & 6 & 0.36 & 0.55 & Çok İyi \\
14 & 15 & 11 & 0.18 & 0.05 & Testten çıarılmalı \\
15 & 53 & 20 & 0.52 & 0.47 & Çok İyi \\
16 & 45 & 14 & 0.42 & 0.44 & Çok İyi \\
17 & 63 & 37 & 0.72 & 0.37 & İyi \\
18 & 27 & 10 & 0.26 & 0.24 & Düzeltilmeli \\
19 & 59 & 21 & 0.57 & 0.55 & Çok İyi \\
20 & 51 & 19 & 0.50 & 0.46 & Çok İyi \\
21 & 60 & 19 & 0.57 & 0.59 & Çok İyi \\
22 & 49 & 10 & 0.42 & 0.56 & Çok İyi \\
23 & 49 & 22 & 0.51 & 0.39 & İyi \\
24 & 47 & 17 & 0.46 & 0.43 & Çok İyi \\
25 & 66 & 24 & 0.65 & 0.60 & Çok İyi \\
26 & 66 & 38 & 0.75 & 0.40 & Çok İyi \\
27 & 60 & 17 & 0.55 & 0.62 & Çok İyi \\
\hline
\end{tabular}

$\mathrm{D}_{\ddot{\mathrm{u}}}$ : Soruya doğru cevap veren üst gruptaki öğrenci sayısı

$\mathrm{D}_{\mathrm{a}}$ : Soruya doğru cevap veren alt gruptaki öğrenci sayıs1

$P$ : Madde güçlük indeksi

$\mathrm{r}_{\mathrm{jx}}$ : Madde ayırt edicilik indeksi

Madde ayırıcılık gücü indeksi Tablo 7'ye göre yorumlanmıştır. Madde ayırıcılık gücü indeksi 0.30 ve daha büyük bir değerde ise madde testte kullanılabilmektedir. $\mathrm{Bu}$ değer 0.20 ve 0.30 arasında ise maddenin düzeltilerek yeniden yazılması, 0.20 'den daha küçük olan maddelerin ise testten çıkarılması gerekmektedir.

Tablo 7.

Madde ayırıcılık gücü indeksi ve buna bağll olarak maddenin değerlendirilmesi

\begin{tabular}{ll}
\hline Madde ayırıcılı gücü indeksi & Maddenin değerlendirilmesi \\
\hline$>0.40$ & Çok iyi bir madde \\
$0.0-0.39$ arası & Oldukça iyi bir madde ama geliştirilebilir \\
$0.0-0.29$ arası & Düzeltilmeli ve geliştirilmeli \\
$<0.20$ & Çok zayıf bir madde, mutlaka testten çıkarılmalı \\
\hline
\end{tabular}

Madde analizi sonucunda 14. sorunun testten çıkarılması, 18. sorunun ise düzeltilmesi gerektiği ortaya çıkmıştır. Diğer soruların madde ayırıcılık gücü indeksi 0.30 'dan büyük olduğu için testte herhangi bir değişikliğe uğramadan kullanılmasına karar verilmiştir.

\section{Yapı Geçerliği}

Örneklem büyüklüğünün faktör analizine uygun olup olmadığını sınamak içim KMO ve Bartlett testine bakılır (Seçer, 2015b) KMO değerinin 0.7 ile 0.8 arasında çıkmasının yeterli olduğu belirtilmiştir (Akt: Seçer, 2015b) Tablo 8'de görüldüğü gibi KMO değeri 0.78 çıkmıştır. Veri setinin faktör analizine uygunluğunu tespit etmek için son işlem Bartlett testidir. Bu test sonucunda ise p değerinin anlamlı çıkması yani 0.05 'ten küçük olması gereklidir (Seçer, 2015a). Bu araştırmada p değeri 0.00 olarak bulunmuştur. KMO ve Bartlett testi sonuçlarına göre başarı testinden elde edilen veriler analiz için uygundur (Tablo 8).

Tablo 8 .

KMO ve Bartlett testi

\begin{tabular}{llc}
\hline Kaiser-Meyer-Olkin Measure of Sampling Adequacy. & $\mathbf{. 7 8}$ \\
\hline Bartlett's Test of Sphericity & Approx. Chi-Square & 989.357 \\
& Df & 351 \\
& Sig. & .000 \\
\hline
\end{tabular}


Fen bilimleri dersi öğretim programına göre (2013) Elektrik enerjisi ünitesi Ampullerin Bă̆lanma Şekilleri ve Elektrik Enerjisinin Dönüşümü olmak üzere iki başlık altında toplanmaktadır. Başarı testi soruları bu kazanımlar doğrultusunda hazırlandığı için Doğrulayıcı Faktör Analizi (DFA) ile soruların faktörlere dağılımı sınanmıştır. Birbiriyle bağlantılı olan yapıların oluşturduğu kavramlara faktör denir, bunların ortak boyutları vardır (Güriş ve Astar, 2015). Testi oluşturan maddelerin sahip olduğu ortak boyutların yapısı bilindiğinde yani belirli amaçlar doğrultusunda maddeler hazırlandığında açımlayıcı faktör analizi yerine doğrulayıcı faktör analizi kullanılabilmektedir (Güriş ve Astar, 2015; Türkmen, Baykal ve Seren, 2011; Kılınç, 2011).

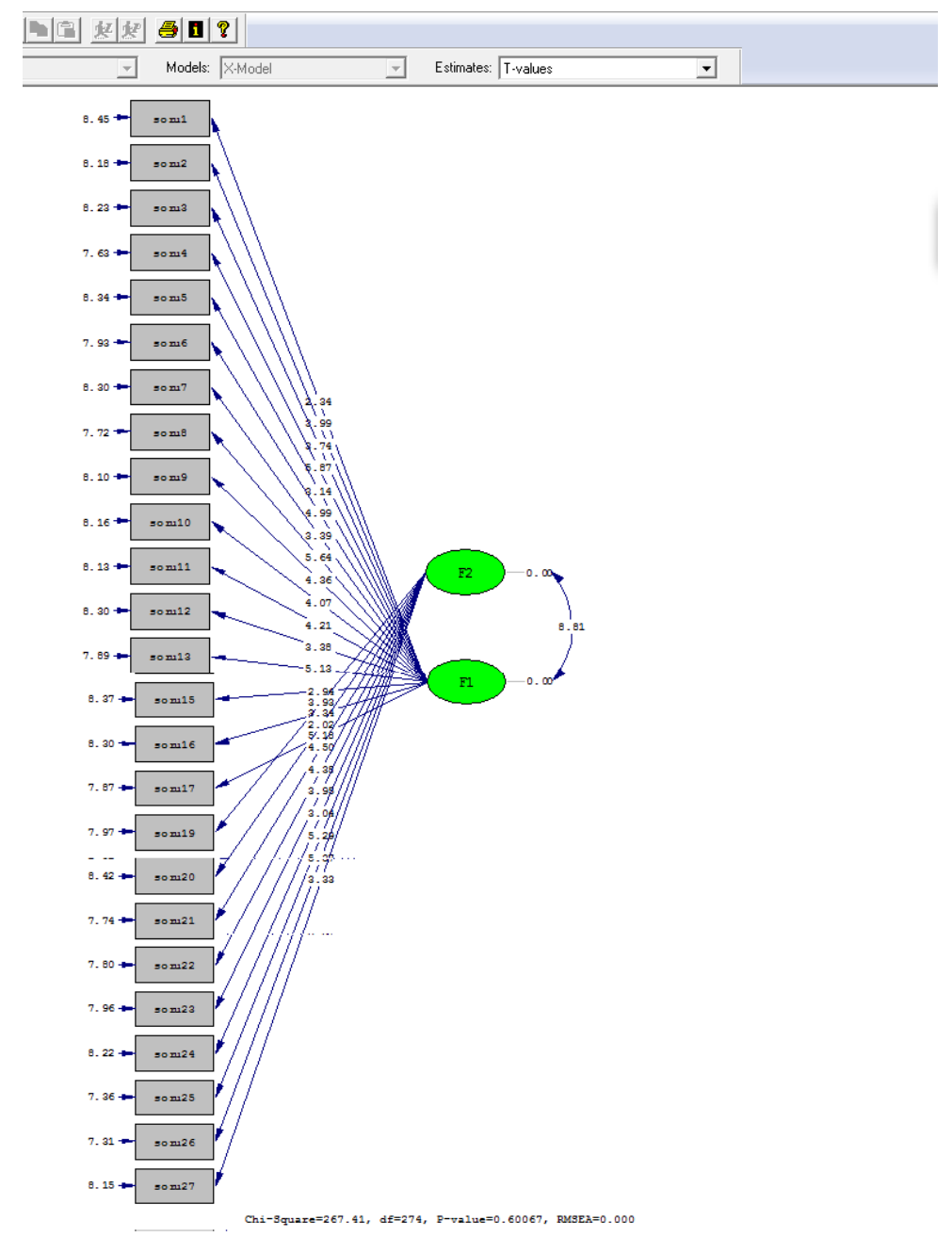

Şekil 1. Maddeler çıkarıldıktan sonra t değerleri 

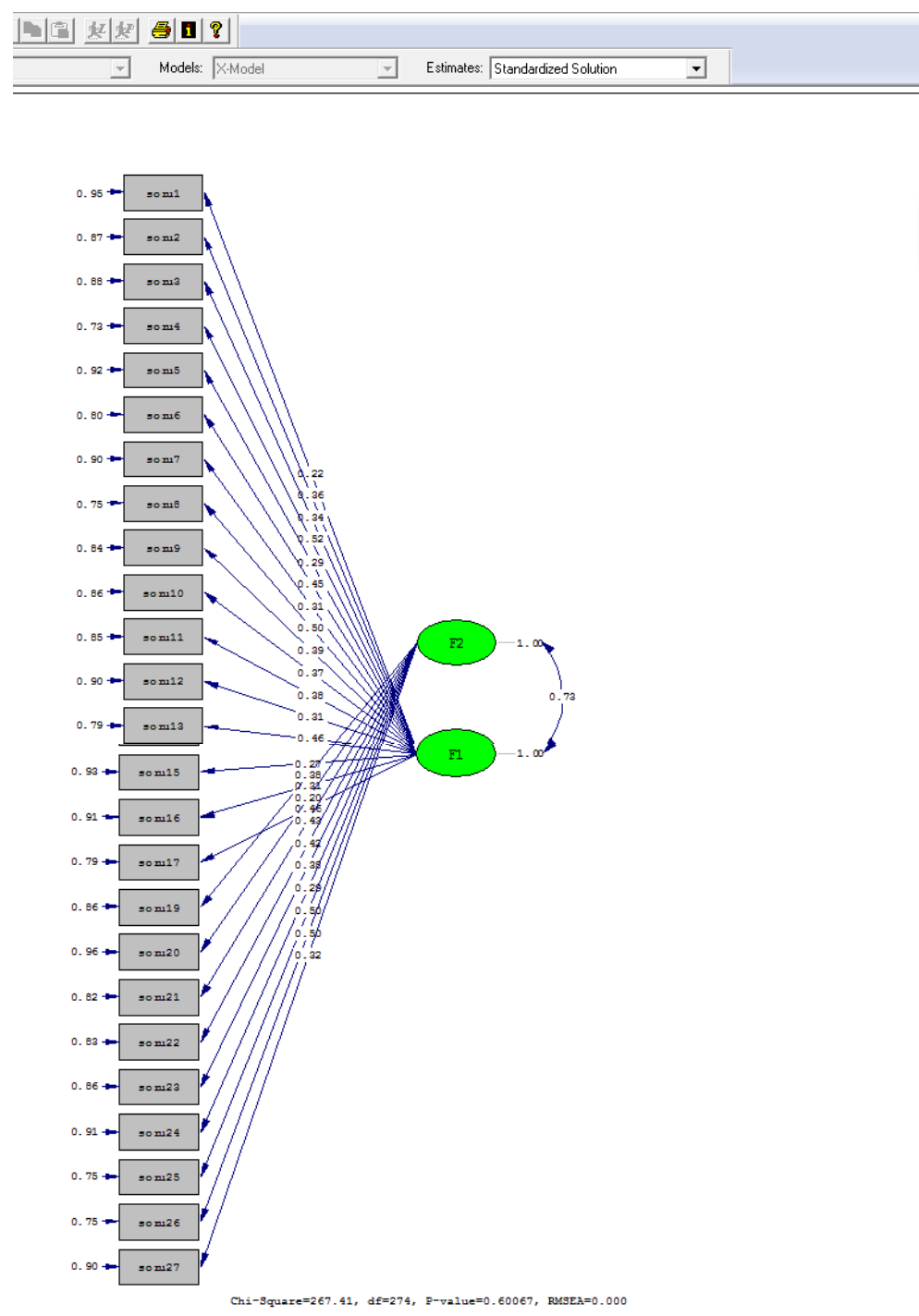

Şekil 2. Maddeler çıkarıldıktan sonra faktör yük değerleri

DFA sonucunda maddelerin sahip olduğu faktör yüklerinin 0.22 ile 0.52 arasında olduğu görülmektedir. Faktör yük değerinin en az 0.20 olması beklenir (Avşar, 2007). Maddelerin $t$ değerleri incelendiğinde, $t$ değerlerinde bir uyumsuzluk ortaya çımamış, faktör yük değerleri de yeterli gelmiştir. Seçkin (2015b), DFA'da öncelikli faktör yük değerlerinin daha sonra da $t$ değerlerinin incelenmesi gerektiğini belirtmiștir. Maddelerin $t$ değerleri incelendiğinde 14. ve 18. maddenin $t$ değerlerinin kırmızı renkte görünmesi maddelerin testten tümüyle çıkarılması gerektiğini göstermektedir. Madde 14 ve 18 testten çıkarıldıktan sonra analiz işlemi tekrarlanmış $t$ değerlerinde bir uyumsuzluk olmadığı, faktör yük değerlerinin de yeterli geldiği görülmüsstür (Şekil 1 ve Şekil 2).

Model uyum indeksleri aşağıdaki tabloda gösterilmiştir. Uyum indekslerinin hangilerinin standart kabul edileceği hususunda bir uzlaşmaya henüz varılamamıştır (Akt: Çapık,2014). Bu çalışmada sınanan uyum indeksleri Tablo 9'da verilmiştir. 
Tablo 9.

Model uyum indeksleri

*Akt: Seçer, 2015a

\begin{tabular}{llll}
\hline Uyum indeksi & Kabul edilebilir sınır & Mükemmel uyum sınırı & $\begin{array}{l}\text { EEBT için bulunan } \\
\text { değer }\end{array}$ \\
\hline NNFI & $=.90$ ve üzeri & $=.95$ ve üzeri & 1.02 \\
IFI & $=.90$ ve üzeri & $=.95$ ve üzeri & 1.03 \\
GFI & $=.85$ ve üzeri & $=.90$ ve üzeri & 0.87 \\
CFI & $=.95$ ve üzeri & $=.97$ ve üzeri & 1.00 \\
AGFI & $=.85$ ve üzeri & $=.90$ ve üzeri & 0.85 \\
RMSEA & $=.050$ ve <.050 & $=.080$ ve <.08 & 0.00 \\
$X^{2} / \mathrm{s} d$ & Bulunan değer istatistiksel olarak anlamsı olmalıdır $X^{2} / \mathrm{s} d=3$ 'ten küçük olmalıdır. \\
\hline
\end{tabular}

Öncelikle Ki-kare değerinin $\left(X^{2}\right)$ 267,41 ve df değerinin 274 olduğu görülmüştür. Değerler yerine yazıldığında $X^{2} / \mathrm{s} d=267.41 / 274<3$ olduğu için bulunan değer istatistiksel olarak anlamsızdır. Diğer model indekslerinden Root Mean Square Error of Approximation (RMSEA) değerinin 0.00 olduğu ve mükemmel uyum sinırında olduğu görülmektedir. Non-Normed Fit Index (NNFI) $=1.02$, Cooperative Fit Index $(\mathrm{CFI})=1.00$, Incremental Fit Index (IFI) = 1.03, Goodness of Fit Index (GFI) $=0.87$, Adjusted Goodness of Fit Index (AGFI) $=0.85$ olarak saptanmıştır. Böylelikle fit indekslerinin de kabul edilebilir olduğu görülmüştür. LISREL üzerinde yapılan DFA neticesinde geliştirilen başarı testinin 25 maddeden oluştuğu ve bu maddelerin 2 faktör altında toplandığı anlaşılmıştır. Ölçeğin geçerliliğinin sağlanmasında önemli bir veri olan faktör analizi ile istenen sonuç alınmıştır.

\section{Güvenirlik}

Güvenirlik, ölçme aracının tutarlı sonuçlar vermesiyle ilgilidir. Ölçümlerin tesadüfi olmadığını, farklı zamanlarda aynı sonuçlara ulaşıldığını gösterir. Bir testin iç tutarlılığını belirlemek için Cronbach Alpha değerine bakılır. Cronbach Alpha değeri 0 ile 1 arasında bir sayıdır. Bir testin güvenilir kabul edilmesi için cronbach alpha kat sayısının 0.7 ve üzerinde bir değer alması gerekmektedir (Heale ve Twycross, 2017; Güriş ve Astar, 2015). Bu çalışmada EEBT cronbach's alpha güvenirlik katsayısı 0.78 olarak bulunmuştur. Testteki 14 ve 18. Maddeler çıkarılınca Cronbach Alpha güvenirlik katsayısı 0.79 olarak hesaplanmıştır. Testteki alt faktörlerin güvenirlik kat sayısı faktör 1 için 0.70 ve faktör 2 için 0.66 olarak bulunmuştur (Tablo 10). Cronbach Alpha güvenirlik katsayısı 0.60 ile 0.80 arasında olması orta düzeyde güvenirliğe işaret etmektedir (Özdamar, 1999). Testin ikinci alt boyutu için bu değer kabul edilebilir bulunmuştur.

Tablo 10

Testin alt boyutlarına ilişkin güvenirlik kat sayıları

\begin{tabular}{ll}
\hline Test alt boyutları & Cronbach alpha değeri \\
\hline Faktör 1 & 0.70 \\
Faktör 2 & 0.66 \\
Tüm sorular toplam & 0.79 \\
\hline
\end{tabular}

Test-tekrar test güvenirliğini hesaplamak için araştırmacının okulunda bulunan 32 sekizinci sınıf öğrencisine ön testten yaklaşık 20 gün geçtikten sonra ikinci kez aynı test uygulanmıştır. Ön test ve son test arasındaki korelasyon değerinin 0.80 olarak hesaplanması test-tekrar test güvenirliğinin sağlandığını göstermektedir (Tablo 11). Seçer (2015a), ölçeğin test tekrar test güvenirliğini belirlemek için iki uygulama arasındaki korelasyona bakmanın yeterli olduğunu belirtmiştir.

Tablo 11.

Bă̆ımlı t testi sonucu

\begin{tabular}{llllll}
\hline & $\mathbf{N}$ & $\mathbf{X}$ & $\mathbf{S S}$ & $\mathbf{t}$ & $\mathbf{p}$ \\
\hline Ön test & 32 & 12.91 & 5.18 & 1.413 & 0.168 \\
Son test & 32 & 12.13 & 4.70 & & \\
\hline
\end{tabular}




\section{Testin son haline ilişkin veriler}

Geliştirilen Elektrik Enerjisi Başarı Testine ait istatistiksel sonuçlar Tablo 12'de verilmiştir. Test 255 öğrenciye uygulanmıştır. Yapılan analizler sonucu toplam soru sayısı 25 'e düşürülmüştür. Testin güvenirlik kat sayıs1 0.79 , ortalama madde güçlüğü 0.52 ve ortalama madde ayırt ediciliği 0.46 olarak hesaplanmıştır.

Tablo 12.

EEBT'nin madde analizine yönelik istatistiksel sonuçlar

\begin{tabular}{ll}
\hline EEBT soru sayısı & $\mathbf{2 5}$ \\
\hline Uygulanan kişis sayısı & 255 \\
Cronbach alpha güvenirlik katsayısı & 0.79 \\
Ortalama madde güçlüğ̈u & 0.52 \\
Ortalama madde ayırt ediciliği & 0.46 \\
\hline
\end{tabular}

\section{SONUÇ VE TARTIŞMA}

Bu çalışmanın sonucunda 25 maddeden oluşan "Elektrik Enerjisi Başarı Testi” 7. sınıf öğrencilerinin elektrik enerjisi ünitesinde öğrendikleri bilgileri ölçmek için geçerli ve güvenilir bir ölçme aracı olarak bulunmuştur. Bu çalışmada test geliştirme işlem basamakları şu şekilde belirlenmiş ve takip edilmiştir: Testin geliştirilmesine olan ihtiyacı belirlendikten sonra literatür taraması yapılmış ve madde havuzu oluşturulmuştur. Testin soruları, öğrenme kazanımları dikkate alınarak yeniden yazılmış, kapsam geçerliliğini sağlamak için belirtke tablosu oluşturulmuştur. Daha sonra belirlenen test soruları uzman görüşüne sunulmuş, teste ilk şekli verildikten sonra pilot uygulama yapılmıştır. Pilot uygulamadan sonra elde edilen verilerle madde analizi yapılmıştır. Madde analizinden sonra geçerlik ve güvenirlik çalışması yapılıış ve analizler sonrası teste son şekli verilmiştir. Bu işlemler, Seçer'in (2015a) test geliştirme süreci olarak belirlediği basamaklara uygun olarak yapılmıştır.

Testin ortalama güçlüğünün 0.50 civarında olması yani testin ne çok zor ne de çok kolay olmaması gerekmektedir. Testin ortalama ayırt edicilik değerinin ise 0.40 ve üstü olması beklenmektedir (Yılmazer, 2012). EEBT'nin ortalama madde güçlüğü 0.49 olarak, ortalama madde ayırt ediciliği ise 0.44 olarak hesaplanmıştır. $\mathrm{Bu}$ değerler literatürdeki diğer başarı testleri ile örtüşmektedir. Demir, Kızılay ve Bektaş (2016), yedinci sınıf öğrencilerinin çözeltiler konusundaki akademik başarılarını ölçmek için geliştirdikleri başarı testinin ortalama madde güçlügünnü 0.58 ve ortalama ayırt edicilik indeksini 0.48 olarak hesaplamıştır. Şener ve Taş (2017), beşinci sınıf öğrencilerine yönelik geliştirdikleri başarı testinin ortalama madde güçlüğünü 0.56 ve ortalama madde ayırt ediciliğini 0.49 olarak bulmuşlardır. Kara ve Çeliker (2015) tarafından geliştirilen başarı testinin ortalama güçlük ve ortalama ayırt edicilik değerleri 0.40 civarında bulunmuştur.

Testin Cronbach Alpha güvenirlik kat sayısı 0.79 olarak hesaplanmıştır. Güvenirlik kat sayısının 0.70’in üzerinde olması testin güvenilirliğini ortaya koymaktadır. Demir vd. (2016) hazırladığı başarı testinin güvenirlik kat sayısı 0.73, Özkıdık'ın (2010) 0.81, Gönen, Kocakaya ve Kocakaya'nın (2011) 0.80', Şen ve Eryılmaz 'ın (2011) 0.89'dur. Böylelikle literatürdeki çalışmalara benzer sonuçların ortaya çıktığı görülmektedir. Croanbach Alpha, testlerin iç tutarlılık kat sayısını hesaplamak için daha genel bir yöntem olsa da test geliştirme çalışmalarında farklı güvenirlik kestirme yöntemlerinin kullanıldığı da görülmektedir (Erkan ve Gömleksiz, 2014). Örneğin Akbulut ve Çepni (2013) çalışmalarında Sperman Brown güvenirlik kast sayısını (0.99) kullanmış; Kara ve Çeliker (2015) hazırladıkları başarı testinin güvenirliğini KR-20 güvenirlik kat sayısını (0.76) hesaplayarak sınamıştır.

Madde analizi sonucunda 14. sorunun ayırt ediciliğinin oldukça düşük olduğu tespit edilmiş ve testte çıkarılması gerektiği ortaya çıkmıştır. Doğrulayıcı faktör analizi yapıldığında 18. maddede sorun olduğu ortaya çıkmış, bu maddenin de testten çıkarıldığında yapılan analiz sonucunda model uyum indekslerinin istenilen değerde olduğu görülmüştür. Model uyum indekslerinden RMSEA, NNFI, CFI, IFI, GFI ve AGFI değerleri incelenmiş ve testin iki faktörlü yapısının onaylandığı görülmüsştür. Kılınç (2011) geliştirdiği ölçeğin iki boyutlu yapısını GFI, CFI, NNFI ve RMSEA değerleri ile sınamayı yeterli görmüştür. Türkmen vd. (2011) ölçek geliştirme çalışmalarında model uyum indekslerinden RMSEA, NNFI, NFI, CFI ve RFI'nın değerlerini dikkate alarak ölçeğin beş faktörlü yapısını doğrulamıştır. 
Ölçek geliştirme sürecinde gerçekleştirilen pilot uygulamada, yedinci sınıf öğrencileri için geliştirilmek istenen ölçek zaman sıkıntısı nedeniyle sekizinci sınıf öğrencilerine uygulanmıştır. Konu işlendikten uzun zaman sonra yapılan ölçme işlemi öğrencilerin konuyu hatırlamakta güçlük çekmesine, sınavda aşırı kaygı göstermesine veya gerekenden daha az düzeyde güdülenmesine yol açabilmektedir (Çelik, 2011; Gömleksiz ve Erkan,2014). Çalışmanın güvenirliğini artırmak için testin yedinci sınıf öğrencilerine "Elektrik Enerjisi” ünitesi işlendikten sonra uygulanıp verilerin analiz edilmesi önerilmektedir.

Yapılan çalışma sonucunda 25 sorudan oluşan Elektrik Enerjisi Ünitesi Başarı Testi geliştirilmiştir. Yapılan analizler sonucu test geçerli ve güvenilir bulunmuş, testin yedinci sınıf öğrencilerinin "Elektrik Enerjisi" ünitesindeki akademik başarılarını ölçmede kullanılabilecek uygun bir ölçme aracı olduğu belirlenmiştir (Başarı testi EK-1'de verilmiştir.).

\section{KAYNAKÇA}

Akbulut, H. \& Çepni S. (2013). Bir üniteye yönelik başarı testi nasıl geliştirilir? İlköğretim 7. sınıf kuvvet ve hareket ünitesi. Amasya Üniversitesi Ĕgitim Fakültesi Dergisi, 2(1), 18-44.

Anderson, L.W. \& Krathwohl, D.R. (Eds.) (2001). A taxonomy for learning, teaching, and assessing: A revision of Bloom's taxonomy of educational objectives. New York: Addison Wesley Longman.

Atılgan, H., Kan, A. \& Doğan, N. (2009). Ĕgitimde ölçme ve değgerlendirme.(3. Bask1). Ankara: Arı Yayıncılık.

Avşar, F. (2007). Doğrulayıcı faktör analizi ve back depresyon envanteri üzerine bir uygulama. Yüksek Lisans Tezi, Yıldız Teknik Üniversitesi, İstanbul.

Coşkun H., Akarsu, B. \& Kariper, İ. A. (2012). Bilim öyküleri içeren eğitsel oyunların fen ve teknoloji dersindeki öğrencilerin akademik başarılarına etkisi. Ahi Evran Üniversitesi Kırşehir Eğitim Fakültesi Dergisi (KEFAD), 13(1), 93-109.

Çapık, C. (2014). Geçerlik ve güvenirlik çalışmalarında doğrulayıcı faktör analizinin kullanılması. Anadolu Hemşirelik ve Sağllk Bilimleri Dergisi, 17(3), 196-205.

Çelik, D. (2011). Okullarda ölçme değerlendirme nasıl olmalı? İstanbul: MEB. Demir, N., Kızılay, E. \& Bektaş, O. (2016). 7. sınıf çözeltiler konusunda başarı testi geliştirme: Geçerlik ve güvenirlik çalışması Necatibey Eğitim Fakültesi Elektronik Fen ve Matematik Eğitimi Dergisi (EFMED), 10(1), 209-237.

Demirci, N. \&Yağc1, Z. (2008). Fen bilgisi dersi “yaşamımızı yönlendiren elektrik” ünitesinin çoklu zeka kuramı etkinliklerine göre değerlendirilmesi. Ĕgitimde Kuram ve Uygulama, 4(1), 79-97.

Erkan, S \& Gömleksiz M. (Ed.). (2014). Eğitimde ölçme ve değerlendirme. (3. Baskı). Ankara: Nobel yayınları.

Engelhardt P. V. \& Beichner R. J. (2004). Students understanding of direct current resistive electrical circuits. American Journal of Physics, 72(1), 98-115.

Gezgincan, S., Murat, M. \& Yalçın, M. (2005). Ölçme ve değerlendirme. Ankara: Nadir Kitap.

Gönen, S., Kocakaya S. \& Kocakaya F. (2011). Dinamik konusunda geçerliliği ve güvenilirliği sağlanmış bir başarı testi geliştirme çalışması. Yüzüncü Yll Üniversitesi Eğitim Fakültesi Dergisi, 8(1), 40-57.

Günel, M., Atila M. E. \& Büyükkasap, E. (2009). Farklı betimleme modlarının öğrenme amaçlı yazma aktivitelerinde kullanımlarının 6. sınıf yaşamımızdaki elektrik ünitesinin öğrenimine etkisi. İlköğretim Online, 8(1), 183-199.

Güriş, S. \& Astar, M. (2015). Bilimsel araştırmalarda SPSS ile istatistik (2. Baskı). İstanbul: Der Yayınları. Haladyna, T.M. (2004). Developing and validating multiple-choice test items. (3. Bask1). New Jersey: Lawrence Erlbaum Assocaiates.

Heale, R. Twycross A. (2017). Validity and reliability in quantitative studies. Evidence Based Nursing 18, 6668. Web: http://ebn.bmj.com/content/ebnurs/18/3/66.full.pdf (11.03.2018).

İdin, Ş. (2015). Zenginleştirilmiş eğitim uygulamalarının 7. Sınıf öğrencilerinin fen bilimleri ders başarıları tutumlarl ve kalıcılı̆̆a etkisi. Doktora Tezi, Hacettepe Üniversitesi İlköğretim Anabilim Dalı, Ankara.

Kara, F. \& Çeliker, D. (2015). Development of achievement test: Validity and reliability study for achievement test on matter changing. Journal of Education and Practice, 6(24), 21-26.

Kılınç, M. (2011). Öğretmen adaylarının eğitimde ölçme ve değerlendirmeye yönelik öz yeterlilik algı ölçeği. Ahi Evran Üniversitesi Kırşehir ĕgitim Fakültesi Dergisi,12(4), 81-93.

Marzano, R. J. (2006). Classroom assessment \& grading that work. Virginia: Association for Supervision and Curriculum Development.

Milli Eğitim Bakanlığı (MEB). (2013). Fen bilimleri öğretim programı. Ankara.

Milli Eğitim Bakanlığ (MEB). (2017). Fen bilimleri öğretim programı. Ankara. 
National Research Council (NRC), 2001. Clasroom assessment and the National Science Education Standards. Washington, D.C.: National Academy Press. DOI: https://doi.org/10.17226/9847.

Özkıdık, K. (2010). İlköğretim 7. Sinıf fen ve teknoloji dersi yaşamımızdaki elektrik ünitesinin öğretiminde işbirlikli öğrenme yönteminin öğrenci başarısına ve tutuma etkisi. Yüksek Lisans Tezi, Gazi Üniversitesi İlköğretim Ana Bilim Dalı, Ankara.

Seçer, İ. (2015a). Psikolojik test geliştirme ve uyarlama süreci SPSS ve LiSREL uygulamaları. Ankara: Anı Yayıncilik.

Seçer, İ. (2015b). SPSS ve LISREL ile pratik veri analizi.(2. Baskı). Ankara: Anı Yayınc1lık.

Stiggins, R. J., Arter, J. A., Chappuis, J. \& Chappuis, S. (2006). Classroom assessment for student learning doing it right-using it well. New Jersey: Pearson Education.

Şan, İ. \& Akdağ, M. (2016). Sinav yoluyla ögrenme yöntemi ve örnek uygulamaları. Ankara: Nobel Yayınc1lık.

Şen, H. C. \& Eryılmaz A. (2011). Bir başarı testi geliştirme çalışması: Basit elektrik devreleri başarı testi geçerlik ve güvenirlik araştırması. Yüzüncü Yll Üniversitesi Eğitim Fakültesi Dergisi 8(1), 1-39.

Şener, N. \& Taş, E. (2017). Developing achievement test: A research for assessment of 5th grade biology subject. Journal of Education and Learning, 6(2), 254-271.

Şeker, H. \& Gençdoğan, B. (2006). Psikolojide ve eğitimde ölçme aracı geliştirme. Ankara: Nobel Yayıncılık.

Tekin, H. (1987). Eğitimde ölçme ve değerlendirme. (5. Baskı). Ankara: MESO Yayınevi.

Türkmen, E., Baykal, Ü., Seren, Ş. \& Altundaş, S. (2011). Hasta güvenliği kültürü ölçeğinin geliştirilmesi. Anadolu Hemşirelik ve Sağllk Bilimleri Dergisi, 14(4), 38-46).

Waugh, C. K. \& Gronlund N. E. (2013). Assessment of student achievement. (10th ed). Boston: Pearson.

Webb, N. L. (2007). Issues related to judging the alignment of curriculum standards and assessments. Applied Measurement in Education, 20(1), 7-25.

Yllmazer, U. (2012)Eğitimde ölçme ve değerlendirme. Teorem Yayınc1lı. Web: https://kaanonaran.files.wordpress.com/2015/02/ec49fitimde-c3b6lc3a7me-dec49ferlendirme.pdf (11.03.2018). 


\section{EK-1 \\ Sevgili Öğrenciler, \\ Katılımınız için teşekkürler. \\ Feyza Dumanoğlu \\ Ad Soyad: \\ Sinıf: \\ 1) Fen bilimleri öğretmeni öğrencisi Seda'dan sadece bir ampul, bir pil ve bir kablo kullanarak basit bir elektrik devresi kurmasını istemiştir. Seda aşağıda verilen devrelerden hangisini kurarsa ampul ışık verir? \\ A)<smiles>C1CCCCC1</smiles><smiles>C1CCCC1</smiles><smiles>CC1CCCCC1</smiles>

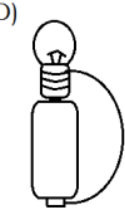

7. sınıf elektrik enerjisi ünitesi kazanımlarının değerlendirilmesi amacıyla geliştirilen bu test, 27 çoktan seçmeli sorudan oluşmaktadır. Öğrencilerin fen bilimleri dersine yönelik başarılarını arttırabilmek ve fen öğrenimini geliştirmemiz için sizden beklenen bu testi ciddiyetle çözmenizdir. Lütfen tüm soruları okuyunuz ve testi eksiksiz tamamlayınız. Testten aldığınız puanlar fen bilimleri dersi notunuzu etkilemeyecektir. Süre 40 dakikadır.

2) Elektrik enerjisi ile ilgili aşağıda verilen bilgilerden hangisi yanlıştır?

A) Elektrik enerjisi bir çeşit enerji aktarımıdır.

B) Elektrik enerjisi 1sı enerjisine dönüşsebilir.

C) Ampulde elektrik enerjisinin tamamı 1 şık enerjisine dönüșür.

D) Elektrikli araçlar elektrik akımının iletilmesi sayesinde çalışır.

3) Aşağıdakilerden hangisinin devreye paralel bağlanması devrede kısa devre oluşmasına sebep olur?

A)

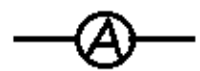

C)

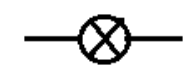

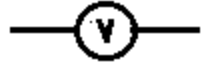

D)
4) Bir öğrenciye 2 ampul, 1 pil ve yeterli sayıda kablolar veriliyor. Bunlarla öğrenciden önce seri bağlı devre yapıp sonra da bozup paralel bağlı devre yapması isteniyor. Öğrencinin kurduğu devrelerden hangileri doğrudur?

A)

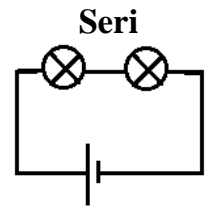

Paralel

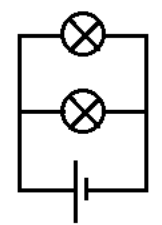

B)
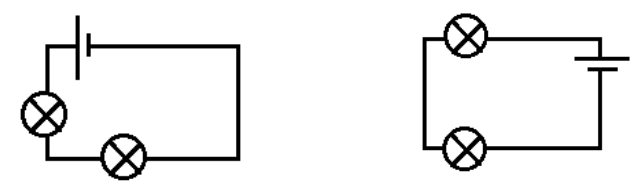

C)
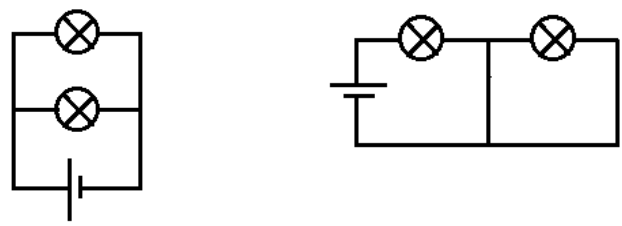

D)
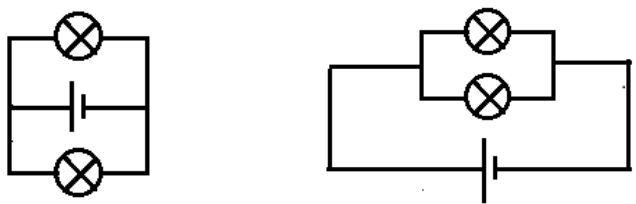
5) Ampermetre ile ilgili bazı bilgiler verilmiştir.

I. Devreye seri bağlanır.

II. Devreden geçen akımı ölçer.

III. Direnci çok küçüktür.

Buna göre verilen bilgilerden hangileri doğrudur?
A) I ve II
B) I ve III
C) II ve III
D) I, II ve III

6) Özdeş lambalar ve piller kullanılarak şekildeki elektrik devreleri kuruluyor.
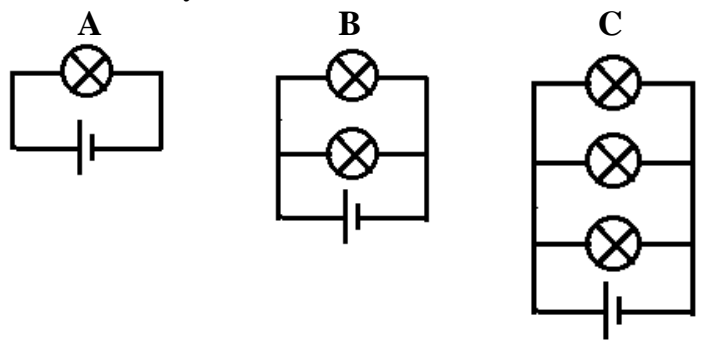

Buna göre, A, B, C lambalarının parlaklıkları arasındaki ilişkiyi gösteren grafik aşağıdakilerden hangisidir?
A)

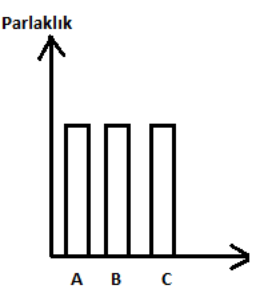

C)

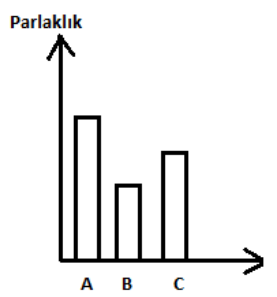

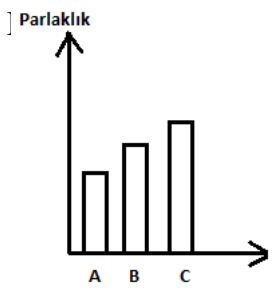

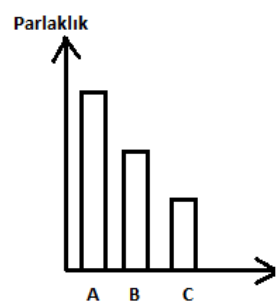

7) Direncin birimine adı verilen bilim insanı kimdir?
A) Andre Marie Ampere
B) Alessandro Volta
C) Georg Simon Ohm
D) Isaac Newton

8) Şekildeki elektrik devresinde B ampulünün yanına C ampulü seri bağlı olarak ekleniyor. Bu durumda aşağıdakilerden hangisi söylenebilir? (Tüm ampuller özdeştir.)

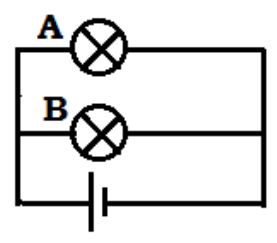

1. durum

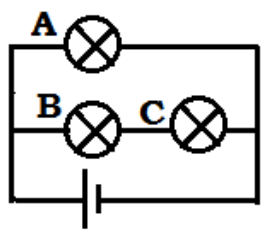

2. durum

(C ampulu ekleniyor)
A) İkinci durumda A ampulünün parlaklığı artar. B) Birinci ve ikinci durumda A ampulü üzerinden geçen akım aynıdır.

C) İkinci durumda B ampulünün parlaklığı artmıştır.

D) İkinci durumda B ampulü üzerinden daha fazla akım geçer.

9) Voltmetre ile ilgili aşağıda verilen ifadelerden hangisi doğrudur?

A) Her devrede mutlaka olması gerekir.

B) Devreye paralel bağlanır.

C) Direnci çok küçüktür.

D) Devreden geçen akımı ölçer.

10) Ali, "Seri bağlı devrede ampul sayısı arttıkça ampul parlaklığg azalır" hipotezini kanıtlamak istiyor.

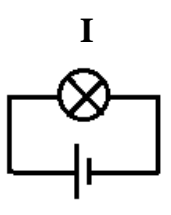

III

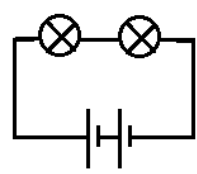

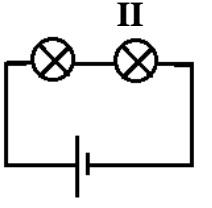

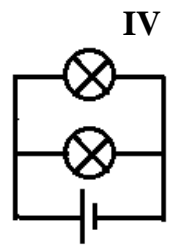

Buna göre hangi devreleri kullanması gerekir?
A)I ve II
B) I ve III
C)II ve III
D) I ve IV 


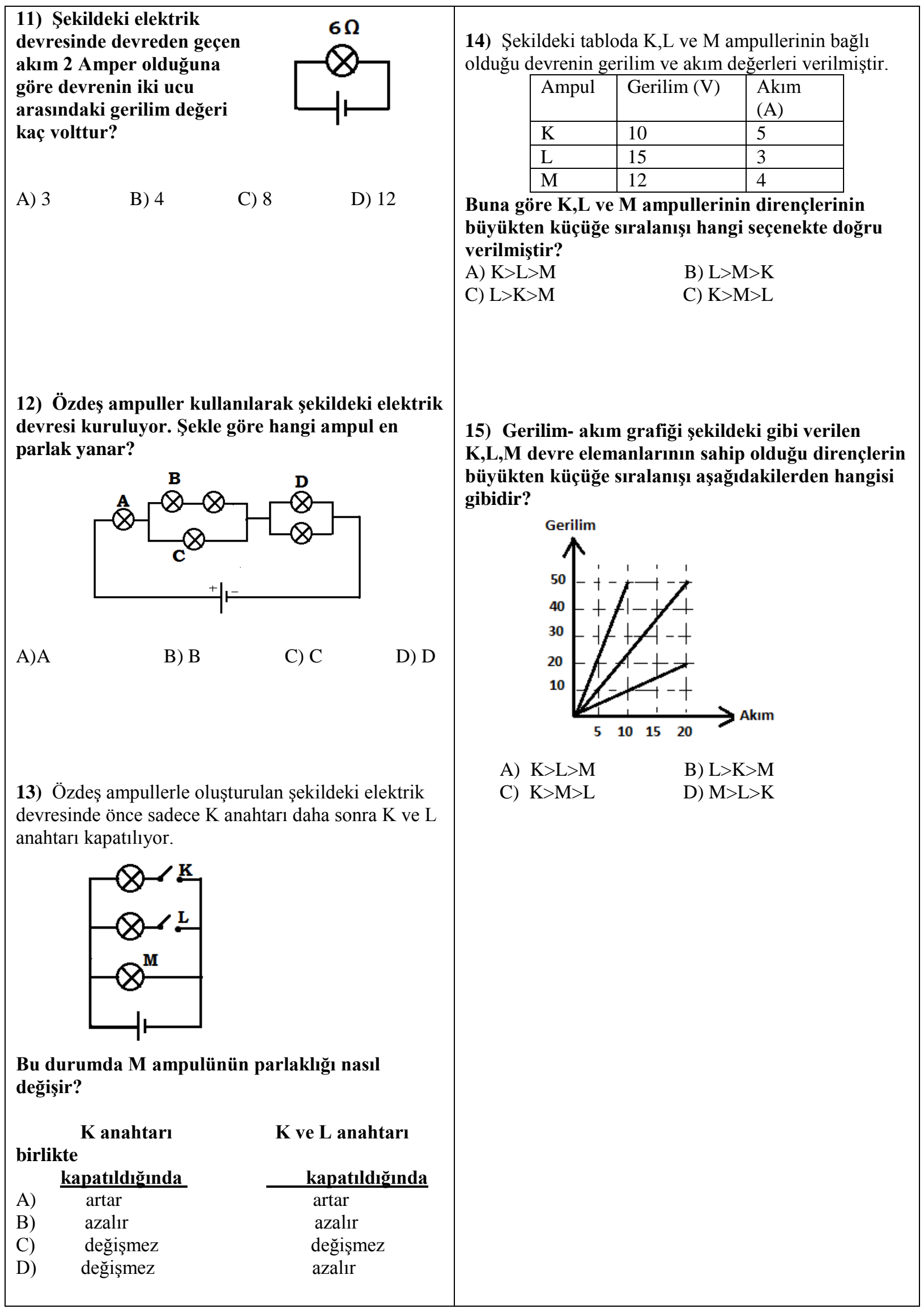


16) Özdeş 3 ampul ve 1 pil kullanılarak şekildeki elektrik devresi kuruluyor.

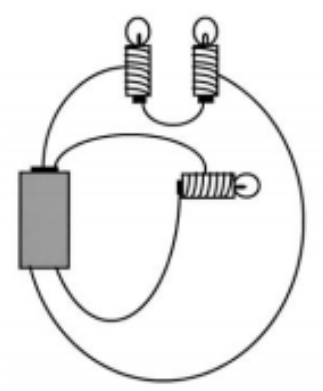

Yukarıda verilen elektrik devresinin şematik gösterimi aşağıdakilerden hangisi olabilir?

A)
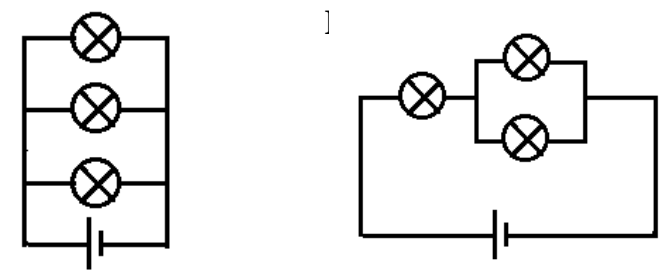

C)
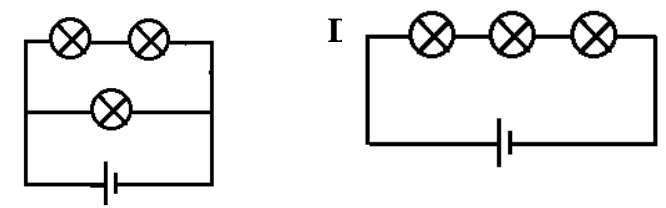

17)
I. Mikser
II. Robot
III. Elektrik motoru

Yukarıda verilenlerden hangileri elektrik enerjisini hareket enerjisine dönüștürür?
A)I ve II
B) I ve III
C) II ve III
D) I, II ve III

18)
Ampuller elektrik enerjisinin tamamını 1şık enerjisine dönüştürür.

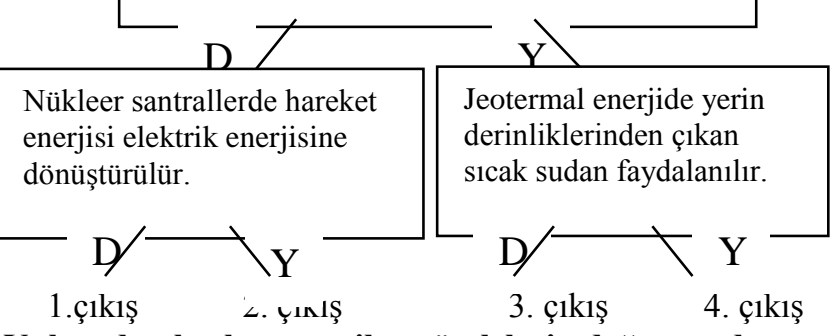

Nükleer santrallerde hareket enerjisi elektrik enerjisine dönüştürülür.

Yukarıdan başlayıp verilen cümlelerin doğru ya da yanlış olduğunu değerlendirerek aşağıya inen bir öğrenci kaç numaralı çıkışa ulaşır?
A) 1
B) 2
C) 3
D) 4

19) Fen bilimleri dersinde enerji dönüşümlerini geliștirdiği bir projeyle anlatması istenen Ali, şöyle bir jeneratörlü sistem kurmuştur.

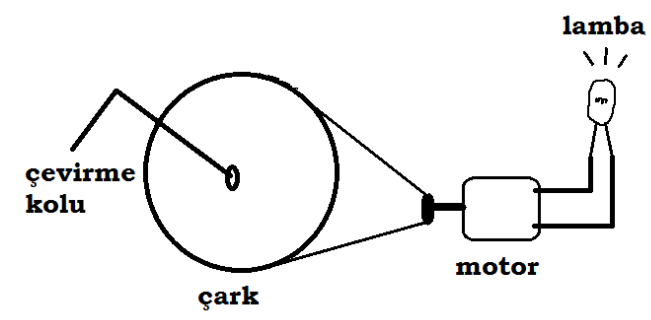

Ali çarkın kolunu hızlıca çevirdikçe, motora bağlı olan ip motorun da dönmesini sağlar ve sonunda ampul yanar. Buna göre meydana gelen enerji dönüşümleri sırasıyla hangi seçenekte verilmiştir?
A) Elektrik enerjisi- hareket enerjisi- 1şı k enerjisi
B) Hareket enerjisi- 1s1 enerjisi-1şık enerjisi
C) Elektrik enerjisi-1sı enerjisi-1şık enerjisi
D) Hareket enerjisi- elektrik enerjisi- 1şık enerjisi 
20) Dört öğrenci enerji dönüşümleriyle ilgili bilgiler veriyor. Hangi öğrencinin verdiği bilgi doğrudur?

A) Ayşe: Rüzgar enerji santralinde 1sı enerjisi elektrik enerjisine dönüştürülür.

B) Beyza: Hidroelektrik santrallerde suyun hareket enerjisinden yararlanılır.

C) Cemil: Termik santrallerde potansiyel enerji elektrik enerjiye dönüştürülür.

D) Derya: Nükleer enerji santralinde 1şı enerjisinden faydalanilır.

21) Aşağıda verilen şekilde bir hidroelektrik santralde üretilen enerjinin evlerimizdeki lambaların yanmasına kadar geçen sürede uğradığı dönüşümler verilmiştir.

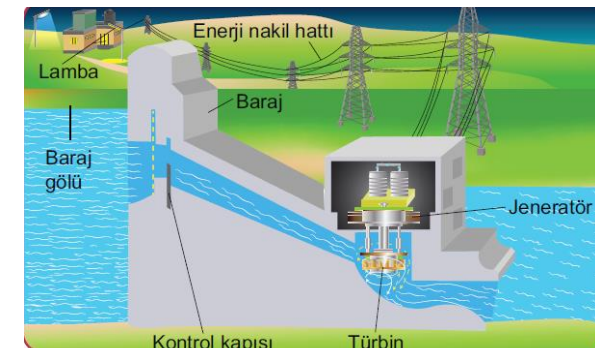

Buna göre şekilde gösterilen enerji dönüşümü aşağıdakilerden hangisinde doğru verilmiştir?

A) Hareket enerjisi-elektrik enerjisi- 1şık enerjisi

B) Elektrik enerjisi- hareket enerjisi- 1şı enerjisi

C) Elektrik enerjisi- hareket enerjisi- 1si enerjisi

D) Hareket enerjisi- 1Sı enerjisi- 1şık enerjisi

22) Aşağıdaki tabloda bazı enerji kaynakları verilmiştir. $\mathrm{Bu}$ enerji kaynaklarının hangi gruba ait olduğunun " $\mathrm{X}$ " işareti ile belirtilmesi istenmiştir.

\begin{tabular}{|c|c|c|}
\cline { 2 - 3 } \multicolumn{1}{c|}{} & $\begin{array}{c}\text { Yenilenebilir } \\
\text { enerji } \\
\text { kaynağ }\end{array}$ & $\begin{array}{c}\text { Yenilenemez } \\
\text { enerji } \\
\text { kaynağ1 }\end{array}$ \\
\hline $\mathrm{Su}$ & & \multicolumn{1}{|c|}{} \\
\hline Rüzgar & & \\
\hline Petrol & & \\
\hline Jeotermal & & \\
\hline
\end{tabular}

Buna göre verilen tablonun doğru işaretlenmiş hali aşağıdakilerden hangisinde gösterilmiştir?

A)

B)
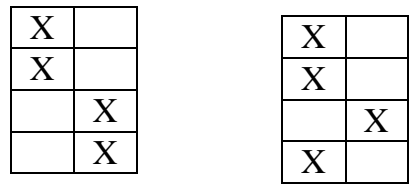

C)

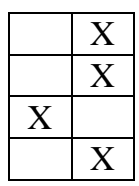

D)

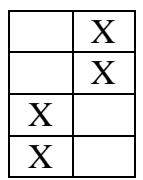

23) Elektrik faturası yüksek gelen Ayşe Hanım, enerji tasarrufu yapıp aile ekonomisine katkı sağlamaya karar verir. Buna göre Ayşe Hanım aşağıdakilerden hangisini yapmalıdır?

A) Fırında yemek pişirirken fırının kapağını sürekli açıp kapatmalıdır.

B) Çamaşırları gerekmedikçe yüksek sıcaklıkta yıkamamalıdır.

C) Buzdolabını güneş alacak yere yakın yerleştirmelidir.

D) Kitap okurken çalışma masasını değil tüm odayı aydınlatmalıdır.

24) 17 Öğretmeni Ali’ye üzerinde çeşitli aletlerin resminin olduğu kartlar vermiştir ve elektrik enerjisini 1S1 enerjisine dönüştüren araçların olduğu kartları göstermesini istemiştir. Ali'nin açtığı kartlar aşağıdaki gibidir.

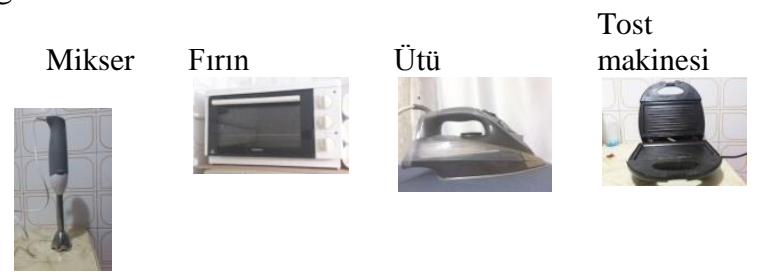

Ali hangi kartı yanlış açmıştır?
A) Mikser
B) Firın
C) Ütü
D) Tost makinesi

25) Bir ilçenin belediye başkanı enerji tasarrufu sağlamak için 2013 yılından başlayarak ilçedeki tüm okullardaki klasik ampulleri, led ampullerle değiştirme kararı almıştır.

Aşağıdaki grafikte Sancaktepe ilçesine bağlı tüm okullarda klasik ampul yerine led ampul kullanıldığında sağlanan enerji tasarruf miktarının yıllara bağlı değişimi verilmiştir.

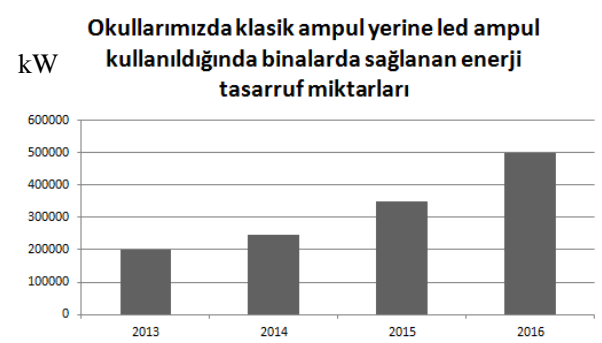

Bu grafiğe göre aşağıdakilerden hangisi söylenemez?

A) Her geçen yıl enerji tasarruf miktarı artmıştır.

B) Led ampuller, klasik ampullere göre daha ucuzdur.

C) Evlerimizde klasik ampuller yerine led ampuller kullanılırsa elektrik faturasını azaltmak mümkündür.

D) Grafiğe göre elektrik faturasının en fazla geldiğg yıl 2013 yilıdır. 


\title{
Development of Electrical Energy Achievement Test
}

\author{
Feyza DUMANOĞLU \\ Science Teacher \\ feyzadumanoglu@gmail.com \\ Behiye BEZİR AKÇAY \\ İstanbul University, Istanbul//TÜRKIYE \\ bbezir@gmail.com
}

Citation: Dumanoğlu, F. \& Bezir Akçay, B. (2018). Development of Electrical Energy Achievement Test. EKafkas Journal of Educational Research, 5(2), 20-39.

\section{Extended Summary}

Purpose: The aim of this study is developing a measurement tool to assess seventh grade students' academic achievement in Electrical Energy Unit.

Method and Findings: The participants of this study were 255 eight graders who were studying in three different public schools in Istanbul in the 2016-2017 academic year. In order to developing achievement test 10 steps were followed.

1. Defining the necessity for test: Due to lack of appropriate achievement tests about Electrical Energy Unit, developing a new reliable and valid achievement test was essential to assess seventh grade students learning.

2. Literature review and collecting a variety of questions: According to objectives of this unit, 39 questions collected from a variety of sources such as textbooks, high school entrance exams and identifying students' level exams.

3. Writing items: Questions were examined and similar questions were eliminated thus the number of questions was reduced to 27 . These items except questions written by researcher were rewritten by researcher.

4. Making a table of specifications: In order to give the proof that this test has content validity, the table of specifications was made. Test items were classified according to Revised Bloom Taxonomy.

5. Taking the expert opinions: Two Turkish teachers, four science teachers, one research assistant in the department of physics and an instructor examined the questions on the basis of comprehensibility of questions, fluency in questions, suitability for target group and consistency in scientific knowledge.

6. Constructing the first version of test: Questions were edited in the light of the experts opinions. An explanatory instruction about the aim of study was inserted to the test.

7. Applying the test: Electrical Energy Achievement Test (EEAT) consist of 27 items was applied 255 eight graders. Sample size should be more than 200 (Haladyna, 2004).

8. Item anaylsis: Firstly all students' EEAT results were scored. One point is awarded for each correct answer and 0 point is given for each wrong or blank answer. Students' total score arranged in descending order and students divided into three groups. Item difficulty and item discrimination were analyzed taking into consideration of lower group ( $\mathrm{n}=69)$ and upper group $(\mathrm{n}=69)$ scores. Item 14 was not as qualified as other questions so it was eliminated.

9. Reliability and validity analysis: The data analyzed via SPSS 24 and Lisrel 9.30 programs.Electrical Energy Unit consists of two parts which are"Connecting Light Bulbs" and "Transformation of Electrical Energy" respectively. Because of the fact that questions were written according to these two factors, confirmatory factor analysis was performed. Based on confirmatory factor analysis question 18 were omitted. These two factors were verified. Confirmatory factor analysis can be useful when the factors are known (Güriş and Astar, 2015; Türkmen, Baykal and Seren, 2011; K1lınç, 2011). Model fit indices were examined.. The values of model fit indexes which were NNFI (1.02), IFI (1.03), GFI (0.87), CFI (1.00), AGFI (0.85) and RMSEA $(0.00)$ were satisfactory.

After two item were omitted, Cronbach's alpha reliability coefficient calculated as 0.79. EEAT was administrated 30 students as re-test and test-retest reliability was found 0.80 .

10. Final version of the test: After item analysis item 14 were omitted and according to confirmatory factor analysis results item 18 were omitted. Final version of EEAT consists of 25 multiple choice questions. 
Conclusion and Discussion: Reliability coefficient of Electrical Energy Achievement Test consisting of 25 questions was found 0.79 in this study. Confirmatory factor analysis was performed and two factors were found suitable. Name of the factors are "Connecting Light Bulbs" and "Transformation of Electrical Energy".

This study indicates that the Electrical Energy Achievement Test consisting of 25 questions is valid and reliable instrument to assess seventh grade students' achievement. 